Article

\title{
Lower Reproductive Rate and Lamb Survival Contribute to Lower Lamb Marking Rate in Maiden Ewes Compared to Multiparous Ewes
}

\author{
Dayna Hutchison, Bronwyn E. Clarke (D), Serina Hancock (D), Andrew N. Thompson (D), Elise Bowen \\ and Caroline Jacobson *(i)
}

check for

updates

Citation: Hutchison, D.; Clarke, B.E.; Hancock, S.; Thompson, A.N.; Bowen, E.; Jacobson, C. Lower Reproductive Rate and Lamb Survival Contribute to Lower Lamb Marking Rate in Maiden Ewes Compared to Multiparous Ewes. Animals 2022, 12, 513. https:// doi.org/10.3390/ani12040513

Academic Editor: Stephen J.G. Hall

Received: 15 January 2022

Accepted: 17 February 2022

Published: 18 February 2022

Publisher's Note: MDPI stays neutral with regard to jurisdictional claims in published maps and institutional affiliations.

Copyright: (C) 2022 by the authors. Licensee MDPI, Basel, Switzerland. This article is an open access article distributed under the terms and conditions of the Creative Commons Attribution (CC BY) license (https:// creativecommons.org/licenses/by/ $4.0 /)$.
Centre for Animal Production and Health, Murdoch University, South Street, Murdoch, WA 6150, Australia; 32901095@student.murdoch.edu.au (D.H.); bronwyn.clarke@murdoch.edu.au (B.E.C.);

s.hancock@murdoch.edu.au (S.H.); andrew.thompson@murdoch.edu.au (A.N.T.); elisejbowen@gmail.com (E.B.)

* Correspondence: c.jacobson@murdoch.edu.au

Simple Summary: The reproductive performance of ewes in their first breeding season (maiden ewes) can be poorer and more variable than at subsequent breeding seasons. However, the extent and causes of the poorer reproductive performance of maiden ewes on Australian sheep farms are not well understood. We used a survey of Australian sheep farmers to compare the reproductive performance of maiden ewes in their first breeding season to multiparous ewes (ewes that have been bred two or more times) on the same farms. We found that the difference in lamb marking rate between non-Merino ewe lambs and multiparous ewes on the same farm was $58 \%$, and for maiden Merino two-tooth ewes, the difference in marking rate compared to multiparous ewes was $22 \%$ lower. Poorer reproduction in maiden ewes was due to a combination of poorer reproductive success to mid-pregnancy (reproductive rate), plus poorer survival of lambs between mid-pregnancy and lamb marking. Reproductive performance for maiden Merino two-tooth ewes was correlated with multiparous ewes on the same farm, whereas the reproductive performance of non-Merino ewe lambs was more variable and not associated with the reproductive performance of their multiparous counterparts. The reproductive efficiency of maiden ewes could be improved by addressing factors that improve the reproductive rate and lamb survival between scanning and lamb marking.

\begin{abstract}
Suboptimal reproductive performance of maiden (primiparous) ewes remains a source of inefficiency for the Australian sheep industry. However, the extent and causes of the poorer reproductive performance of maiden ewes on Australian sheep farms are not well understood. Here, we show the reproductive performance of maiden ewes relative to their multiparous counterparts on the same farms across Australia using a cohort survey. The difference in marking rate for non-Merino maiden ewe lambs compared to multiparous ewes was $58 \%$ (74 vs. $132 \%$; $p<0.001)$, and this was attributable to a $50 \%$ difference in reproductive rate (109 vs. $159 \% ; p<0.001)$ and $16 \%$ difference in lamb survival to marking (67 vs. $83 \% ; p<0.001$ ). The difference in marking rate for maiden Merino two-tooth ewes lambing at approximately 2 years-of-age compared to mature multiparous ewes was $22 \%$ ( 80 vs. $102 \%$; $p<0.001$ ) and this was attributable to a $24 \%$ difference in reproductive rate $(108$ vs. $132 \% ; p<0.001)$ and $3 \%$ difference for lamb survival $(75$ vs. $78 \% ; p<0.05)$. Positive correlations for reproduction traits (reproductive rate, lamb survival and marking rate) between maidens and multiparous ewes were observed for maiden Merino two-tooth ewes $(p<0.001)$, but these correlations were weak or non-existent for non-Merino ewe lambs. Strategies to improve both reproductive rate and lamb survival can address the poorer and more variable reproductive performance of maiden ewes.
\end{abstract}

Keywords: lamb survival; scanning rate; sheep reproduction; maiden ewe 


\section{Introduction}

Improving the reproductive performance of maiden (primiparous) ewes lambing for the first time at either approximately 12 months of age (ewe lambs) or 24 months of age (two-tooths) has been identified as a priority for the Australian sheep industry [1]. It is widely accepted that the reproductive performance of maiden ewes is generally poorer and more variable compared to multiparous ewes. However, the reproductive performance of maiden ewes on commercial farms in Australia has not been well quantified. Marking rate, which describes the number of lambs marked (tailed and/or tagged) relative to the number of ewes joined (mated) to rams, has increased in Australia by about $15 \%$ over the last 30 years [2,3]. This has been attributed to changes in flock structure and greater adoption of husbandry practices, including differential management of single- and multiple-bearing ewes to optimise the condition score [4,5]. However, industry data for marking rates are based predominantly on mature multiparous and mixed-age ewes and do not differentiate between maidens and multiparous ewes [2,3]. Improved understanding of the reproductive performance of maiden ewes can inform benchmarks for reproduction and strategies aimed at improving whole-flock reproductive performance. Apart from the economic benefits from improved reproductive performance, improving ewe and lamb survival can improve animal welfare and address societal demands for ethical livestock production [6].

Marking rate is a function of reproductive rate or the number of foetuses identified at pregnancy scanning during mid-pregnancy and foetal and lamb survival between scanning and lamb marking. A range of factors is known to contribute to lower marking rates in ewe lambs compared to multiparous ewes, including lower fertility and ovulation rates, higher embryo loss between conception and scanning and lower foetus and lamb survival between scanning and marking (reviewed by Kenyon et al. [7]). There has been less work on the performance of ewe lambs in Australia compared to New Zealand. Thompson et al. [8] and Clune et al. [9] recently reported considerable variation in reproductive rate and or marking rates between different flocks of ewe lambs. In these studies, the average reproductive rate was $108 \%$, and foetal and lamb losses between scanning and marking exceeded 35\%. Lamb mortality in the perinatal period was the primary cause of lamb mortality after scanning, although abortions were an important contributor in some flocks [9]. However, neither study compared the performance of ewe lambs and multiparous ewes or focussed on the relative contributions of reproductive rate and foetus and lamb survival to the poorer and more variable marking rates for ewe lambs.

Surprisingly, even less is known about the reproductive rate and lamb survival for maiden two-tooth ewes compared to multiparous ewes. A large study on 43 farms over 4 years in South Australia found that reproductive rate was approximately 13\% lower for maiden two-tooth ewes, and survival of both single and twin lambs was approximately 10\% lower compared to multiparous ewes on the same farm [10]. Other work has reported no significant differences in lamb survival between maiden two-tooth ewes and multiparous ewes across eight flocks around Australia over five years [11]. Lockwood et al. [12] reported no differences in lamb survival between maiden two-tooth ewes and multiparous ewes from survey respondents in south-eastern Australia, whereas, in New Zealand, survival was reported to be $6 \%$ lower for maiden two-tooth ewes than mature multiparous ewes. Whilst differences in lamb survival between maiden two-tooth ewes and mature multiparous ewes may be less than observed between maiden ewe lambs and multiparous ewes, even small differences impact national marking rates due to the large number of maiden two-tooth ewes joined annually.

This study aimed to determine the difference in reproductive performance between maiden and multiparous ewes across major sheep producing regions of Australia to inform strategies to improve reproductive performance in maiden ewes. We hypothesised that (i) maiden ewes joined either as ewe lambs or two-tooth ewes will have lower marking rates than multiparous ewes, and (ii) this will be due to a combination of lower reproductive rate and lower lamb survival between scanning and marking. 


\section{Materials and Methods}

\subsection{Study Design and Setting}

This study surveyed sheep producers from Western Australia, South Australia, Victoria, New South Wales and Tasmania. Sheep producers were recruited for the survey between 2019 and 2021 and completed a questionnaire focused on reproductive performance for ewes that lambed between 2018 and 2020. This included data recorded at pregnancy scanning (typically conducted 70-90 days from the start of mating period) and lamb marking (tail docking).

\subsection{Study Participants}

Sheep producers were contacted by the project team via phone or e-mail. Contact details for producers were obtained through their participation in other sheep reproduction studies, or from commercial providers of sheep pregnancy scanning and livestock production advisors. Livestock production advisors and pregnancy scanning providers also contacted clients on behalf of the project team to confirm interest and eligibility for participation before providing contact details to the project team. The survey was also promoted to sheep producers using social media and in newsletters by sheep breeders' societies, sheep production extension organisations, grower groups and livestock production advisors.

Participants were provided with a cover letter outlining the aims of the project, requirements for eligibility to participate and information relevant for providing informed consent to participate. Respondents were selected for inclusion in the survey on the basis that: (a) they separately managed maiden ewes mated as ewe lambs (7-10 months at start of mating period) or two-tooth ewes (16-22 months at start of mating period), (b) utilised pregnancy scanning by transabdominal ultrasonography to determine the number of foetuses for maiden and multiparous ewes and (c) were able to determine lamb survival to marking for maiden and multiparous ewes on the same property, which generally required managing maiden ewes separately from multiparous ewes during lambing. Very few responses were received for Merino ewe lambs and non-Merino maiden two-tooth ewes during the first 12 months of the study, so they were subsequently excluded from the survey, and only non-Merino ewe lambs and Merino two-tooth ewes were targeted thereafter.

The most common reasons for exclusion from study were: (a) the number of foetuses was not determined for some or all of the maiden or multiparous ewes, and/or (b) maiden ewes were mixed with multiparous ewes during lambing and thus lamb survival to marking could not be determined separately for maiden and multiparous ewes.

\subsection{Questionnaire and Measurements}

The questionnaire could be completed by the producer either as a hard copy or electronically, or was completed by the research team via a telephone interview with the producer. Follow-up contact with producers was made via telephone, text message or e-mail, where only partial data had been returned. Pre-testing of the questionnaire was done initially with research staff at Murdoch University and then with farmers participating in other sheep production projects to ensure that the questionnaire layout and questions were clear and unambiguous. Modifications to the question design were made in response to feedback during the pre-testing phase. Further refinements to questions were made throughout the study in response to feedback from respondents and following preliminary analysis of the data that informed the statistical methods.

The questionnaire included four questions about general farm details, including location, farm size and the number of Merino and non-Merino ewes on the farm. The remainder of the questionnaire was divided into three sections that included reproductive data for (a) maiden ewes at scanning, (b) maiden ewes at lamb marking and (c) multiparous ewes at scanning and lamb marking. Sheep data were collected for each mob of maiden ewes and for the total population of multiparous ewes for each farm. Data collected for maiden ewes at pregnancy scanning included the number of ewes mated, ewe age, ewe breed, breed of ram used, month of mating period, body condition score at mating, 
number of ewes scanned, number of foetuses identified at scanning and number of nonpregnant (dry) ewes. Maiden ewe data collected at lamb marking included mob or paddock name, number of ewes, pregnancy status (single, twin, triplet or mixed), month lambing commenced, condition score at lambing, number of lambs marked and number of ewe deaths (if known). Data for multiparous ewes included the number of ewes, ewe breed, breed of rams used, number of ewes scanned, number of foetuses identified at scanning, number of non-pregnant ewes, number of lambs marked and number of ewe deaths (if known).

Respondents had the option of providing additional data outlining the management of maiden ewes, including the length of the mating period, average condition score at mating and lambing, predominant pasture types and feed-on-offer and supplementary feeding strategies. Condition score was reported on a scale of 1 (very thin) to 5 (very fat), as previously described [13]. For feed-on-offer and condition score, there was a question asking if respondents had measured or estimated these values and whether they had previously received training in performing these measurements.

Validity of the sample size for respondents was assessed using an assumption of $10 \%$ expected difference in mean for reproductive parameters (traits), expected standard deviation of 20 and power of test 80 . Based on this, $90 \%$ confidence intervals could be determined with 36 responses and $95 \%$ confidence intervals determined with 49 responses.

\subsection{Quantitative Variables}

Reproductive rate (\%) for maiden and multiparous ewes were determined based on the number of foetuses identified at pregnancy scanning expressed relative to the number of ewes scanned. Lamb survival (\%) was determined based on the number of live lambs present at lamb marking expressed relative to the number of foetuses identified at scanning. Marking rate (\%) was determined based on the number of live lambs present at marking expressed relative to the number of ewes joined. Ewe mortality (\%) was determined based on the number of ewe deaths between pregnancy scanning and lamb marking expressed relative to the number of ewes that were pregnant at scanning (i.e., excluded ewes not pregnant at scanning).

\subsection{Statistical Analysis}

Farm location was coded into categories based on the Australian Bureau of Agricultural and Resource Economics (ABARE) region that are based on agricultural profile [2]. Statistical analyses were performed using GENSTAT (VSN International 2017, Hemel Hempstead, UK) and IBM SPSS Statistics (version 24) (IBM 2021, Armonk, NY, USA). Reproductive traits (reproductive rate, lamb survival and marking rate) for maiden and multiparous ewes were compared initially using a paired sample $t$-test (two-tailed), including a $95 \%$ confidence interval of the difference. The assumption of normality of the difference between maiden and multiparous ewes for reproductive traits were tested using a Shapiro-Wilk test. This indicated that the assumption of normality for the difference was not met for reproductive rate and ewe mortality $(p<0.001)$. Subsequently, comparisons of reproductive traits between maiden ewes and multiparous counterparts on the same farm were compared using a two-tailed non-parametric related-samples Wilcoxon signed-rank test. Correlations between reproductive traits for maiden and multiparous ewes on the same farm were determined using bivariate Pearson correlation (two-tailed) and linear regression.

Association between farm, sheep and management factors with reproductive performance traits were analysed with linear mixed-effects models at farm level and mob/paddock level. Models were constructed separately for each of the three reproductive traits (marking rate, reproductive rate and lamb survival) for two maiden ewe age categories (maiden ewe lambs and two-tooth ewes) and two levels (pooled farm data and mob/paddock data), equating to 12 separate models. Ewe management during lambing (separate or combined management of maiden and multiparous ewes), ewe age, ewe breed, ram breed, 
month of mating, condition score at mating, feed-on-offer at mating, pasture type at mating, duration of supplementary feeding between mating and marking (at day 0-50, 50-100, 100-150 and lactation), supplementary feeding method (trail feeding or self-feeder), type of supplementary feed, condition score at lambing, average feed-on-offer and management category at lambing (mixed or separate management of single- and multiple-bearing ewes) were fitted as fixed effects. Mob pregnancy status (mob scanned as single, twin, triplet or mixed litter size) was fitted as a fixed effect at mob level. Year of lambing and farm were fitted as random effects. ABARE region was fitted as a random effect but was not significant and was subsequently removed from the final models. For all analyses, main effects and interactions were only included if they were statistically significant $(p<0.05)$.

\section{Results}

\subsection{Characteristics of Survey Participants}

A total of 79 respondents provided complete data for maiden and multiparous ewes and were eligible for inclusion in the study. Of these, 16 producers contributed data for two years, and three producers contributed data for three years to give a total of 103 survey responses that represented 111,117 maiden ewes managed in 307 mobs from lambing to marking (Table 1). A total of 302,585 multiparous ewes were included in eligible survey responses (Table 1$)$.

Table 1. Distribution of eligible survey responses by state based on number of respondents (farms) and total number of maiden and multiparous ewes.

\begin{tabular}{|c|c|c|c|c|c|c|c|}
\hline & & & \multicolumn{4}{|c|}{ Ewes $(n)$} & \\
\hline & \multicolumn{2}{|c|}{ Respondents ( $n$ ) } & \multicolumn{2}{|c|}{ Maiden } & \multicolumn{2}{|c|}{ Multiparous } & \\
\hline State & $\begin{array}{l}\text { Non-Merino } \\
\text { ewe lambs }\end{array}$ & $\begin{array}{c}\text { Merino two-tooth } \\
\text { ewes }\end{array}$ & $\begin{array}{c}\text { Non-Merino } \\
\text { ewe lambs }\end{array}$ & $\begin{array}{c}\text { Merino two-tooth } \\
\text { ewes }\end{array}$ & Non-Merino & Merino & Total \\
\hline WA & 3 & 11 & 2945 & 14,904 & 9580 & 37,305 & 64,734 \\
\hline SA & 8 & 4 & 8974 & 4645 & 27,338 & 19,520 & 60,477 \\
\hline NSW & 8 & 13 & 15,712 & 8818 & 38,216 & 29,226 & 91,972 \\
\hline VIC & 19 & 11 & 34,387 & 13,728 & 80,448 & 43,931 & 172,494 \\
\hline TAS & 2 & 0 & 7004 & 0 & 17,021 & 0 & 24,025 \\
\hline Total & 40 & 39 & 69,022 & 42,095 & 172,603 & 129,982 & 413,702 \\
\hline
\end{tabular}

Respondents were located across five Australian states (Table 1). The mean farm size was 3750 hectares (range: $230-115,000$ hectares), and the mean number of breeding ewes per farm was 4762 (range: 477-25,000 ewes).

Characteristics for the management of sheep are shown in Table 2. Maiden Merino ewes were joined to Merino rams as two-tooth ewes to lamb at approximately two years-ofage with mean recorded age at mating of 18.5 months. The non-Merino ewe lambs included a range of different breeds, such as composite, Suffolk and Dorper. These were joined with maternal or terminal non-Merino rams to lamb at approximately one year of age with a mean age at mating of 8 months. Differential management during lambing based on ewe litter size was used by $47 \%$ of respondents ( $66 \%$ ewes) for maiden ewe lambs and $57 \%$ of respondents (61\% ewes) for maiden Merino two-tooth ewes (Table 2).

The mean length of the mating period for maiden ewes was 39 days (Table 3). The condition score prior to lambing was reported by 75 respondents (Table 3), of which 31 (41\%) were based on direct measurement, $35(47 \%)$ were based on estimation and $9(12 \%)$ did not specify the method used. The mean reported condition score prior to lambing for all maiden ewes was 3.1 (Table 3). Feed-on-offer during lambing was reported by only eight respondents, of which three were based on measurement, four were estimated and one did not specify the method used. Eighty-six per cent $(n=68)$ of respondents reported having been trained in the assessment of feed-on-offer and condition scoring. 
Table 2. Maiden ewe management characteristics based on eligible survey responses showing number of responses and number of ewes managed by respondents.

\begin{tabular}{|c|c|c|c|c|}
\hline & \multicolumn{2}{|c|}{ Ewe Lambs } & \multicolumn{2}{|c|}{ Merino Two-Tooth Ewes } \\
\hline & Responses $(n)$ & Ewes $(n)$ & Responses $(n)$ & Ewes $(n)$ \\
\hline \multicolumn{5}{|l|}{ Age at mating (months) } \\
\hline 6 & 1 & 2545 & & \\
\hline 7 & 21 & 33,301 & & \\
\hline 8 & 25 & 28,379 & & \\
\hline 9 & 11 & 5003 & & \\
\hline 10 & 1 & 1361 & & \\
\hline 16 & & & 1 & 460 \\
\hline 17 & & & 3 & 492 \\
\hline 18 & & & 28 & 29,066 \\
\hline 19 & & & 5 & 4898 \\
\hline 20 & & & 3 & 2939 \\
\hline$\geq 21$ & & & 4 & 4213 \\
\hline \multicolumn{5}{|l|}{ Month of mating } \\
\hline November & & & 5 & 1770 \\
\hline December & & & 7 & 4898 \\
\hline January & 1 & 245 & 9 & 12,123 \\
\hline February & 9 & 6188 & 11 & 8703 \\
\hline March & 39 & 43,871 & 9 & 10,770 \\
\hline April & 9 & 18,924 & 2 & 3614 \\
\hline May & 1 & 1361 & - & - \\
\hline June & & & 1 & 190 \\
\hline \multicolumn{5}{|l|}{ Management during lambing } \\
\hline Mixed & 30 & 23,574 & 19 & 16,575 \\
\hline Differential management ${ }^{A}$ & 27 & 46,605 & 25 & 25,493 \\
\hline \multicolumn{5}{|l|}{ Rams used for mating } \\
\hline Maternal & 35 & 37,944 & & \\
\hline Terminal & 22 & 32,235 & & \\
\hline Merino & & & 44 & 42,068 \\
\hline \multicolumn{5}{|c|}{ Supplementary feeding during lambing } \\
\hline Trail feeding & 0 & 0 & 6 & 5656 \\
\hline Self-feeder & 2 & 2753 & 3 & 1861 \\
\hline No supplementary feeding & 30 & 50,027 & 17 & 16,576 \\
\hline Not indicated & 25 & 17,399 & 17 & 17,289 \\
\hline
\end{tabular}

A Ewes scanned with single and multiple fetuses were managed separately during lambing.

Table 3. Characteristics for management of maiden ewes based on eligible survey responses.

\begin{tabular}{|c|c|c|c|c|c|c|}
\hline & \multicolumn{3}{|c|}{ Ewe Lamb Flocks } & \multicolumn{3}{|c|}{ Merino Two-Tooth Flocks } \\
\hline & $n$ & Mean \pm s.e & Range & $n$ & Mean \pm s.e & Range \\
\hline Mating period length (days) & 43 & $40 \pm 1$ & $28-60$ & 36 & $38 \pm 1$ & $28-56$ \\
\hline \multicolumn{7}{|l|}{ Condition score } \\
\hline Mating & 47 & $3.15 \pm 0.04$ & $2.5-4.0$ & 30 & $2.90 \pm 0.06$ & $2.0-3.7$ \\
\hline Lambing & 47 & $3.19 \pm 0.05$ & $2.7-4.0$ & 28 & $3.02 \pm 0.07$ & $2.5-4.0$ \\
\hline Feed-on-offer during lambing (kg DM/Ha) & 6 & $1700 \pm 93$ & $1500-2000$ & 2 & $750 \pm 250$ & $500-1000$ \\
\hline
\end{tabular}

s.e: standard error. DM/Ha: dry matter per hectare.

\subsection{Reproductive Performance in Maiden and Multiparous Ewes}

Marking rate, reproductive rate and lamb survival for maiden and multiparous ewes are shown in Figure 1. A key difference between maiden ewe lambs and maiden Merino two-tooth ewes and both multiparous ewes was the wider variation in lamb survival and, to a lesser extent, reproductive rate and marking rate between flocks (Figure 1b). 


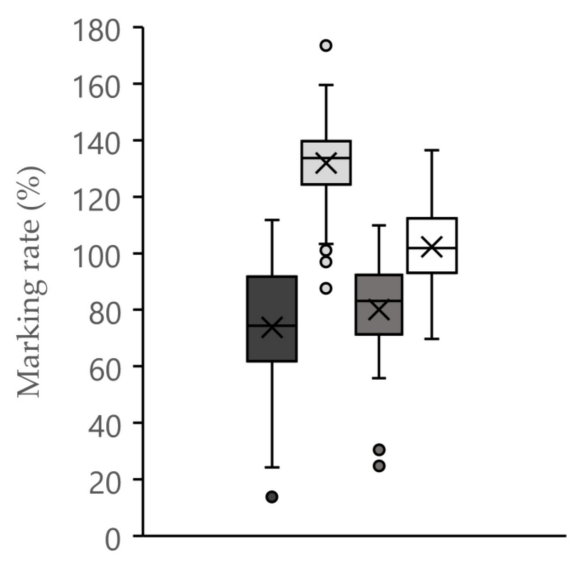

(a)

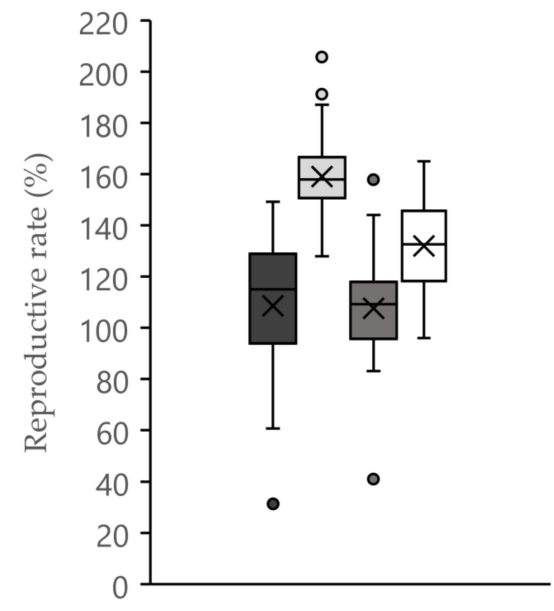

(b)

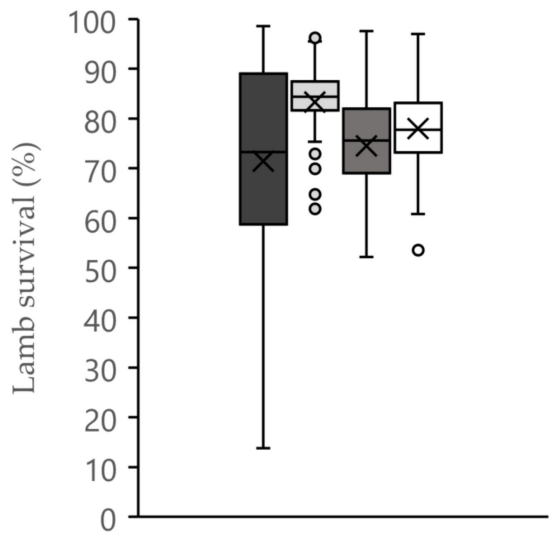

(c)

Figure 1. Box and whisker plot for (a) marking rate, (b) reproductive rate and (c) lamb survival in maiden ewe lambs, Merino two-tooth ewes and equivalent multiparous ewes. $\square$ Maiden non-Merino ewe lambs. $\square$ Multiparous non-Merino ewes. $\square$ Maiden Merino two-tooth ewes. $\square$ Multiparous Merino ewes.

Maiden ewes had a lower marking rate, reproductive rate and lamb survival compared to multiparous ewes on the same farm (Table 4). The average difference in marking rate between maiden and multiparous ewes was 58\% for non-Merino ewe lambs and $22 \%$ for maiden Merino two-tooth ewes (Table 4). Lower marking rate in ewe lambs was attributable to differences of $51 \%$ for reproductive rate and $16 \%$ for lamb survival (Table 4 ). The poorer marking rates of maiden Merino two-tooth ewes compared with their multiparous counterparts was largely attributable to a $22 \%$ difference in reproductive rate, whilst the difference for lamb survival was only $3 \%$ (Table 3 ).

Table 4. Comparisons between maiden and mature multiparous ewes for reproductive rate, marking rate and lamb survival with mean \pm standard error, $95 \%$ confidence interval (95\% CI) for the difference and non-parametric related samples Wilcoxon signed-rank test.

\begin{tabular}{|c|c|c|c|c|}
\hline & \multicolumn{2}{|c|}{$\begin{array}{c}\text { Ewe Age Group } \\
\text { Mean } \pm \text { Standard Error }\end{array}$} & \multicolumn{2}{|c|}{ Difference } \\
\hline & Maidens & Multiparous & Mean $(95 \% \mathrm{CI})$ & $p$-Value \\
\hline \multicolumn{5}{|l|}{ Non-Merino ewe lambs } \\
\hline Marking rate (\%) $\mathrm{A}$ & $73.8 \pm 2.8$ & $131.9 \pm 2.0$ & $-58.1(-64.3,-51.9)$ & $<0.001$ \\
\hline Reproductive rate $(\%){ }^{\mathrm{B}}$ & $108.6 \pm 3.7$ & $159.1 \pm 1.9$ & $-50.5(-59.0,-42.1)$ & $<0.001$ \\
\hline Lamb survival (\%) ${ }^{\mathrm{C}}$ & $67.3 \pm 1.4$ & $83.4 \pm 0.9$ & $-16.0(-18.8 .-13.2)$ & $<0.001$ \\
\hline Ewe mortality (\%) $\mathrm{D}$ & $2.6 \pm 0.2$ & $2.8 \pm 0.2$ & $-0.2(-0.8,0.5)$ & 0.378 \\
\hline \multicolumn{5}{|l|}{ Merino two-tooth ewes } \\
\hline Marking rate $(\%) \mathrm{A}$ & $80.1 \pm 2.6$ & $102.3 \pm 2.2$ & $-22.3(-26.9,-17.7)$ & $<0.001$ \\
\hline Reproductive rate $(\%){ }^{B}$ & $107.6 \pm 3.3$ & $131.9 \pm 2.7$ & $-24.4(-29.5,-19.2)$ & $<0.001$ \\
\hline Lamb survival (\%) ${ }^{C}$ & $74.5 \pm 1.6$ & $77.7 \pm 1.3$ & $-3.1(-5.8,-0.5)$ & 0.026 \\
\hline Ewe mortality (\%) D & $1.7 \pm 0.2$ & $2.4 \pm 0.3$ & $-0.7(-1.2,-0.2)$ & 0.006 \\
\hline
\end{tabular}

${ }^{\text {A }}$ Marking rate $=$ lambs marked $/$ ewes mated $\times 100 .{ }^{B}$ Reproductive rate $=$ fetuses scanned $/$ ewe joined $\times 100$. ${ }^{\mathrm{C}}$ Lamb survival $=$ lambs marked (live)/fetuses scanned $\times 100 .{ }^{\mathrm{D}}$ Ewe mortality $=$ ewe deaths between scanning and lamb marking (scanned pregnant)/ewes pregnant $\times 100$.

Ewe mortality of ewe lambs was not different to that of pregnant multiparous ewes (Table 4). However, the difference in mortality of Merino two-tooth ewes compared to their multiparous counterparts was $0.7 \%$ (Table 4 ). 
There were moderate positive correlations between maiden Merino two-tooth ewes and their multiparous counterparts for marking rate, reproductive rate and lamb survival, marking rate and ewe survival (Table 5). In contrast, there was a very weak positive correlation between ewe lambs and their multiparous counterparts for lamb survival and no correlation for reproductive rate, marking rate or ewe survival (Table 5).

Table 5. Linear regression and bivariate Pearson correlation (two-tailed) between reproductive traits in maiden ewes and corresponding measure for multiparous counterparts.

\begin{tabular}{|c|c|c|c|c|c|}
\hline & \multicolumn{3}{|c|}{ Regression } & \multicolumn{2}{|c|}{ Pearson Correlation } \\
\hline & Intercept & Slope & $\mathbf{R}^{2}$ & $\begin{array}{l}\text { Correlation } \\
\text { Co-Efficient }\end{array}$ & $p$-Value \\
\hline \multicolumn{6}{|c|}{ Multiparous ewes vs. non-Merino ewe lambs } \\
\hline Marking rate $(\%) \mathrm{A}$ & 32.40 & 0.314 & 0.050 & 0.223 & 0.096 \\
\hline Reproductive rate $(\%){ }^{B}$ & 118.29 & -0.061 & 0.001 & -0.032 & 0.814 \\
\hline Lamb survival (\%) & 29.55 & 0.460 & 0.079 & 0.280 & 0.035 \\
\hline Pregnant ewe mortality (\%) $\mathrm{D}$ & 2.107 & 0.180 & 0.032 & 0.180 & 0.222 \\
\hline \multicolumn{6}{|c|}{ Multiparous ewes vs. Merino two-tooth ewes } \\
\hline Marking rate $(\%) \mathrm{A}$ & 14.85 & 0.637 & 0.292 & 0.541 & $<0.001$ \\
\hline Reproductive rate $(\%){ }^{B}$ & 4.21 & 0.783 & 0.426 & 0.652 & $<0.001$ \\
\hline Lamb survival (\%) ${ }^{C}$ & 11.02 & 0.823 & 0.389 & 0.635 & $<0.001$ \\
\hline Pregnant ewe mortality (\%) D & 0.822 & 0.368 & 0.434 & 0.659 & $<0.001$ \\
\hline
\end{tabular}

A Marking rate $=$ lambs marked $/$ ewes mated $\times 100 .{ }^{B}$ Reproductive rate $=$ fetuses scanned $/$ ewe joined $\times 100$ ${ }^{\mathrm{C}}$ Lamb survival $=$ lambs marked (live) $/$ fetuses scanned $\times 100 .{ }^{D}$ Pregnant ewe mortality $=$ ewe deaths between scanning and lamb marking (scanned pregnant)/ewes pregnant $\times 100$.

\subsection{Factors Affecting Reproductive Performance of Maiden Ewes}

Higher marking rates were observed for twin- and triplet-bearing ewes compared with single-bearing ewes (Table 6). This was due to the greater number of foetuses in these mobs and not due to a higher lamb survival with the difference in survival for twin lambs compared to single lambs of $11.4 \%$ for ewe lambs and $22.2 \%$ for Merino two-tooth ewes (Table 6 and Figure S1). Reproductive traits were independent of ABARE region, ewe age, ewe breed, ram breed, month of mating, condition score at mating, feed-on-offer at mating, pasture type at mating, condition score at lambing, duration of supplementary feeding, supplementary feeding method, type of supplementary feed or average feed-on-offer $(p<0.05)$.

Table 6. Predicted means \pm standard error for the marking (\%) and lamb survival (\%) according to ewe management group during lambing for non-Merino ewe lambs and maiden Merino two-tooth ewes.

\begin{tabular}{llllll}
\hline \multirow{2}{*}{ Management Group during Lambing } & \multicolumn{2}{c}{ Marking \% } & & \multicolumn{2}{c}{ Lamb Survival \% } \\
\cline { 2 - 3 } \cline { 5 - 6 } & Ewe Lambs & Two-Tooth Ewes & & Ewe Lambs & Two-Tooth Ewes \\
\hline Mixed & $97.3 \pm 2.9$ & $91.4 \pm 5.0$ & & NA & NA \\
Single & $75.2 \pm 2.3$ & $83.3 \pm 3.3$ & & $76.0 \pm 1.6$ & $82.7 \pm 1.8$ \\
Twin & $129.8 \pm 2.3$ & $122.0 \pm 3.6$ & & $64.6 \pm 1.6$ & $60.5 \pm 2.0$ \\
Triplet & $146.0 \pm 7.9$ & NA & & $43.7 \pm 3.9$ & NA \\
\hline
\end{tabular}

NA: not available (not measured or no eligible responses).

\section{Discussion}

Maiden ewes mated as non-Merino ewe lambs or Merino two-tooth ewes produced 44 and 22 fewer lambs to marking per 100 ewes mated than their multiparous counterparts on the same farm. Lower marking rates for maiden compared to multiparous ewes was attributable, albeit to varying degrees, to lower reproductive rate and lower lamb survival. These results support our hypotheses. To our knowledge, this is the first study to compare 
the marking rate of maiden and multiparous ewes and their components on commercial farms across Australia. Development and adoption of management strategies to improve marking rate for non-Merino ewe lambs should focus on improving both reproductive rate and lamb survival as they contributed nearly equally to the differences in marking rate compared to multiparous ewes. By contrast, the poorer marking rate of Merino two-tooth ewes compared with their multiparous counterparts were largely due to differences in reproductive rate. Nevertheless, the development and adoption of strategies to improve marking rates for Merino two-tooth ewes should also focus on improving both reproductive rate and lamb survival. In this study, lamb survival was relatively low for both two-tooth and multiparous Merino ewes, suggesting that improved lamb survival for Merino ewes across all age groups remains an issue for the Australian sheep industry. Further, the economic value of improving reproductive rate is greater when lamb survival is higher [1], and improving lamb survival has implications for improving animal welfare [6].

The 58\% difference in marking rate for non-Merino ewe lambs compared with multiparous ewes across 40 farms in our study was similar to the difference recently reported from nine commercial farms representing more than 300,000 records in New Zealand (72 vs. 142\%) [14]. Likewise, marking rate was more variable between flocks for nonMerino ewe lambs compared with multiparous non-Merino ewes, with the overall average and variation in marking rate between flocks of non-Merino ewe lambs being similar to results reported by both Shorten et al. [14] and Clune et al. [9]. The 22\% difference in marking rate for Merino two-tooth ewes compared to multiparous ewes across 39 farms was greater than the differences measured by Kleemann and Walker [10] on 14 farms in South Australia (70 vs. 86\%) and a recent survey of 1200 Merino producers across Australia (79 vs. 93\%) [15]. Over the last decade, more than 5000 sheep producers in Australia have participated in the extension and adoption programs to improve ewe management and reproductive performance, such as Lifetime Ewe Management [4,5] and Bred Well Fed Well [16], but these programs have only focused on the management of multiparous ewes. Similar extension and adoption programs to improve the reproductive performance of maiden ewes could have a significant impact on national marking rates and lamb supply as non-Merino ewe lambs and Merino two-tooth ewes represent approximately 10 million breeding ewes in Australia [3].

A lower marking rate for non-Merino ewe lambs compared to multiparous ewes on the same farm was attributed to a $51 \%$ difference in reproductive rate and a $16 \%$ difference in lamb survival. The difference in reproductive rate between these age groups was less than other studies, which have ranged from 75 to $124 \%[7,14]$, whereas the difference in lamb survival between these age groups tended to be greater than most other studies where the difference was less than $10 \%$ [14,17-19]. The wider variation in marking rate, reproductive rate and lamb survival between individual flocks of non-Merino ewe lambs was similar to these and other studies, including Clune et al. [9] and Thompson et al. (unpublished data). Improved understanding of the degree of variation and causes of poorer reproductive rate and lamb survival in maiden ewes will inform extension and adoption programs to improve maiden ewe reproductive performance.

The weak and generally non-significant correlation between the reproductive performance of ewe lambs and their multiparous counterparts in the current study hinged on the more variable performance of ewe lambs, whereas the performance of maiden two-tooth ewes was more consistent when compared with their multiparous counterparts on the same farm. Comparisons between studies suggest that the responses in reproductive rate to improved live weight at the start of the mating period and live weight gain during the mating period are much greater for ewe lambs than in multiparous ewes regardless of breed [8,9,20-22]. Recently Paganoni et al. [23] also reported that the effects of live weight and condition score at mating on reproductive rate were greater in ewe lambs compared to two-tooth non-Merino ewes within the same flocks, and the difference between these age groups was greater than the difference between two-tooth and multiparous Merino ewes. Age of mating also influences the reproductive rate of ewe lambs [8], even though 
this was not apparent in the current survey data where almost $90 \%$ of the ewe lambs were 7 or 8 months of age at mating. Collectively, this implies that the reproductive rate and potential marking rate of ewe lambs are more sensitive to management prior to and during mating than is the case for multiparous ewes. Bunter and Brown [24] reported that expression of reproduction at yearling and adult age is a genetically different trait in maternal (non-Merino) ewes. However, heritabilities for reproductive traits typically ranged 5-15\%, which was consistent with low heritabilities for reproduction traits reported in other studies [25-27]. This indicates that whilst progress in reproductive traits can be made with selection, reproductive performance is driven mostly by management. Management strategies to improve the reproductive performance of ewe lambs are more complex and less adopted, which contributes to the poorer and more variable performance of maiden ewes compared to multiparous ewes on commercial farms.

The precise reasons for poorer and more variable survival of lambs born to maiden ewes, especially ewe lambs, compared with their multiparous counterparts were not able to be determined in this study. Maiden ewes were managed separately to multiparous ewes during pregnancy and lambing, and differences in the lambing environment, such as time of lambing, shelter and mob size, could have impacted lamb survival. Whilst the effects of the varying condition score at lambing on the survival of lambs born to two-tooth ewes is likely to be similar to that that observed in multiparous ewes [11], the slightly lower survival of lambs born to two-tooth ewes may reflect their average condition score at lambing, which was reported to be lower than recommended for mature ewes [28]. By contrast, whilst the level of nutrition and live weight change from pregnancy scanning to lambing is likely to influence the survival of lambs born to ewe lambs [29], the average condition score of ewe lambs in the current study was reported to be 3.2 at lambing, which is likely to be close to the optimum. It may, therefore, be that factors other than nutritional management during pregnancy and lambing contributed to the much greater difference in survival of lambs between ewe lambs and multiparous ewes compared to maiden two-tooth ewes and multiparous ewes.

A number of factors may contribute to the survival of lambs between scanning and marking. Important causes of perinatal lamb mortality include dystocia, stillbirths and starvation-mismothering, but these conditions are usually multifactorial and the role of dam parity are not fully understood [30-33]. Clune et al. [9] reported that lamb mortality between birth and marking was the major contributor to lamb loss between scanning and marking for Australian maiden ewe flocks, but that mid-pregnancy abortion caused significant in utero foetal loss in some flocks of ewe lambs. A review of veterinary investigations for abortions and stillbirths submitted to Australian veterinary diagnostic laboratories reported that $81 \%$ of investigations with a diagnosis involved infectious aetiology, with the most common infectious agents implicated being Listeria spp., Campylobacter spp. and Toxoplasma gondii [34]. More recently, Chlamydia pecorum has been associated with abortions and stillbirth for maiden ewe flocks in Australia [35,36]. A recent study reported T. gondii, Neospora caninum and Coxiella burnetii were not important contributors to foetal and lamb mortality maiden ewe flocks on farms in southern Australia [37-39]. Immunological naïvety is considered a risk factor for infectious reproductive diseases, and therefore maiden ewes have a higher risk for infectious causes of abortion because they have had less time to be exposed to infection and develop immunity before pregnancy [40-43]. Consequently, sporadic impacts of abortion and perinatal lamb mortality due to infectious disease could explain some of the variability in lamb survival reported in this study for maiden ewe flocks, and especially ewe lambs. Sporadic impacts of infectious disease on lamb survival could also explain the lack of correlation between lamb survival for ewe lambs and multiparous ewes on the same farm. The impacts of infectious disease on lamb survival for maiden ewes warrants further investigation.

We did not observe any effect of condition score or feed-on-offer on reproductive rate or lamb survival. However, there were very few responses that included data for condition score or feed-on-offer, and of these, a number were estimated rather than measured. Fur- 
thermore, condition score assessment is often subject to operator bias, which could result in between-operator variability in condition score assessment [44]. Other studies have reported associations between condition and reproductive rate and lamb survival, and between feed-on-offer at lambing and lamb survival. Therefore, the absence of effects of condition and feed-on-offer on reproductive traits in our study likely reflects the response numbers and reporting bias rather than the absence of a biological association. Further investigation to validate current recommendations for the condition at mating and during pregnancy for maiden ewes are warranted.

There were several limitations to this study. Surveys were distributed widely using electronic communications via a range of agricultural networks. As such, it was not possible to determine the survey response rate to provide an indication of non-responder bias. The most common differences between respondents and non-respondents cited in feedback were that non-respondents and responses not eligible for inclusion did not utilise pregnancy scanning to count foetuses, nor did they manage maiden and multiparous ewes separately at lambing to distinguish lamb survival and marking rates for both categories. The inclusion criteria generated bias in the sample population because only producers that utilised pregnancy scanning for litter size were eligible for inclusion. Subsequently, the sampled population likely included a higher proportion of ewes that were differentially managed according to litter size compared to the general population. Differential management of single- and multi-bearing ewes was used for $66 \%$ maiden non-Merino ewe lambs and $61 \%$ maiden Merino two-tooth ewes, which was consistent with the adoption rate for producers that had undertaken Lifetime Ewe Management training [5]. It is also possible that producers that have adopted pregnancy scanning were more likely to adopt other management strategies that could impact reproductive performance compared to the broader population. As such, the findings of this study should only be generalised to Australian sheep producers that have adopted pregnancy scanning and should not be extrapolated across the national sheep flock.

\section{Conclusions}

To our knowledge, this is the first study to compare the marking rate for maiden and multiparous ewes and their components on commercial farms across southern Australia. Marking rates for non-Merino ewe lambs and maiden Merino two-tooth ewes were lower than their multiparous counterparts, and this was attributable to a combination of lower reproductive rate and lower lamb survival. Wide variability in both reproductive rate and lamb survival indicates an opportunity for improvement in reproductive performance for maiden ewes through the adoption of strategies that increase the number of foetuses conceived and the number of lambs surviving between pregnancy scanning and lamb marking. Strategies specific to ewe lambs may be required because their reproductive performance was not correlated with multiparous ewes on the same farm.

Supplementary Materials: The following are available online at https:/ /www.mdpi.com/article/10 .3390 /ani12040513/s1, Figure S1 Box and whisker plot of lamb survival in single- and multiple-born progeny of maiden ewe lambs and maiden Merino two-tooth ewes managed according to litter size.

Author Contributions: Conceptualisation, C.J., S.H. and A.N.T.; methodology, C.J., S.H., B.E.C., A.N.T., E.B. and D.H.; questionnaire validation, E.B.; formal analysis, D.H., B.E.C. and C.J.; investigation, D.H., E.B., S.H., B.E.C. and C.J.; resources, S.H., A.N.T. and C.J.; data curation, D.H. and E.B.; writing-original draft preparation, D.H., C.J., B.E.C. and A.N.T.; writing-review and editing, D.H., B.E.C., S.H., A.N.T., C.J. and E.B.; supervision, B.E.C., S.H., A.N.T. and C.J.; project administration, S.H. and C.J.; funding acquisition, C.J., S.H. and A.N.T. All authors have read and agreed to the published version of the manuscript.

Funding: This research was funded by Meat and Livestock Australia (B.AHE.0318). Elise Bowen was supported with a scholarship from Sheep Industry Business Innovation (Department of Primary Industry and Regional Development, Western Australia). 
Institutional Review Board Statement: The study was conducted according to the guidelines of the Australian Code for the Responsible Conduct of Research and approved by the Murdoch University Human Research Ethics Committee (2018/056).

Informed Consent Statement: Not applicable.

Data Availability Statement: The datasets generated and/or analysed during the current study are not publicly available but are available from the corresponding author on reasonable request pending permission from the funding body (Meat and Livestock Australia) and Murdoch University.

Acknowledgments: We thank the sheep producers that provided responses for this study and feedback on the survey design. We thank participating consultants and service providers for providing assistance sourcing farmers eligible for inclusion in the study, including Ken Solly (Solly Business Services), Meg Bell (MacKillop Group), Genstock Kojonup, Leanne Sherriff (Pinion Advisory), Bruce Watt (NSW Local Land Services), Mick O'Neill (Elders), Rex Luers (Nutrien) Pip Houghton (Thomas Elder Consulting), Colin Trengove (University of Adelaide), Gordon Refshauge (NSW DPI), Jim Gordon and Geoff Duddy (Sheep Solutions). We thank Maeve O'Brien for assistance collecting survey responses and data entry. We thank Andrew van Burgel for his advice on the data collation and analyses. We thank Henry Annandale and David Miller for helpful feedback on an honours thesis describing this work. Changes made in response to this feedback was incorporated into the manuscript.

Conflicts of Interest: None of the authors of this paper had a financial or personal relationship with other people or organisations that could inappropriately influence or bias the content of the paper. The funding body (Meat and Livestock Australia) approved the manuscript for publication but was not involved in the collection, analysis or interpretation of data or in the writing of the manuscript.

\section{References}

1. Young, J.M.; Trompf, J.; Thompson, A.N. The critical control points for increasing reproductive performance can be used to inform research priorities. Anim. Prod. Sci. 2014, 54, 645. [CrossRef]

2. Australian Bureau of Agricultural and Resource Economics. About My Region. Available online: https://www.awe.gov.au/ abares/research-topics/aboutmyregion (accessed on 1 November 2021).

3. Trompf, J.; Young, J.; Bowen, E. Review of National Sheep Reproduction and Lamb Survival; Sheep Producers Australia and Animal Health Australia: Canberra, Australia, 2018.

4. Trompf, J.P.; Gordon, D.J.; Behrendt, R.; Curnow, M.; Kildey, L.C.; Thompson, A.N. Participation in Lifetime Ewe Management results in changes in stocking rate, ewe management and reproductive performance on commercial farms. Anim. Prod. Sci. 2011, 51, 866-872. [CrossRef]

5. Thompson, A.N.; Hamill, B.; King, E.; Scott, M.; Trompf, J. Impacts of the Lifetime Ewe Management training program on the Australian sheep industry Anim. Prod. Sci. 2020, 61, clxxxvii.

6. Ferguson, D.M.; Schreurs, N.M.; Kenyon, P.R.; Jacob, R.H. Balancing consumer and societal requirements for sheep meat production: An Australasian perspective. Meat Sci. 2014, 98, 477-483. [CrossRef]

7. Kenyon, P.R.; Thompson, A.N.; Morris, S.T. Breeding ewe lambs successfully to improve lifetime performance. Small Rumin. Res. 2014, 118, 2-15. [CrossRef]

8. Thompson, A.N.; Bowen, E.; Keiller, J.; Pegler, D.; Kearney, G.; Rosales-Nieto, C.A. The number of offspring weaned from ewe lambs is affected differently by liveweight and age at breeding. Animals 2021, 11, 2733. [CrossRef]

9. Clune, T.; Lockwood, A.; Hancock, S.; Thompson, A.N.; Beetson, S.; Campbell, A.J.D.; Glanville, E.; Brookes, D.; Trengove, C.; O'Handley, R.; et al. Abortion and lamb mortality between pregnancy scanning and lamb marking for maiden ewes in southern Australia. Animals 2022, 12, 10. [CrossRef] [PubMed]

10. Kleemann, D.O.; Walker, S.K. Fertility in South Australian commercial Merino flocks: Sources of reproductive wastage. Theriogenology 2005, 63, 2075-2088. [CrossRef] [PubMed]

11. Paganoni, B.L.; Ferguson, M.B.; Kearney, G.A.; Thompson, A.N. Increasing weight gain during pregnancy results in similar increases in lamb birthweights and weaning weights in Merino and non-Merino ewes regardless of sire type. Anim. Prod. Sci. 2014, 54, 727. [CrossRef]

12. Lockwood, A.L.; Hancock, S.N.; Trompf, J.P.; Kubeil, L.J.; Ferguson, M.B.; Kearney, G.A.; Thompson, A.N. Data from commercial sheep producers shows that lambing ewes in larger mobs and at higher stocking rates reduces the survival of their lambs. N. Z. J. Agric. Res. 2020, 63, 246-259. [CrossRef]

13. Kenyon, P.R.; Maloney, S.K.; Blache, D. Review of sheep body condition score in relation to production characteristics. N. Z. J. Agric. Res. 2014, 57, 38-64. [CrossRef]

14. Shorten, P.R.; Edwards, S.J.; Juengel, J.L. The role of reproductive loss on flock performance: A comparison of nine industry flocks. Transl. Anim. Sci. 2021, 5, txab013. [CrossRef] [PubMed] 
15. Sloane, R. Australian Wool Innovation 2017 Merino Husbandry Practices Survey; Australian Wool Innovation Ltd.: Sydney, Australia, 2018.

16. Hancock, S.; Blumer, S.; Trompf, J. Bred Well Fed Well: One day practical workshop delivers behavioural change and improved marking percentage in Australia. In Proceedings of the The International Symposium on the nutrition of Herbivores, Clermont-Ferrand, France, 2-6 September 2018.

17. Corner, R.A.; Mulvaney, F.J.; Morris, S.T.; West, D.M.; Morel, P.C.H.; Kenyon, P.R. A comparison of the reproductive performance of ewe lambs and mature ewes. Small Rumin. Res. 2013, 114, 126-133. [CrossRef]

18. Morel, P.C.H.; Wickham, J.L.; Morel, J.P.; Wickham, G.A. Effect of birth rank and yearling lambing on long-term ewe reproductive performance. Proc. N. Z. Soc. Anim. Prod. 2010, 70, 88-90.

19. Mulvaney, F.J. Investigating Methods to Improve the Reproductive Performance of Hoggets. Ph.D. Thesis, Massey University, Palmerston North, New Zealand, 2011.

20. Adalsteinsson, S. The independent effects of live weight and body condition on fecundity and productivity of Icelandic ewes Animal Sci. 1979, 28, 13-23. [CrossRef]

21. Viñoles, C.; Glover, K.M.M.; Paganoni, B.L.; Milton, J.T.B.; Martin, G.B. Embryo losses in sheep during short-term nutritional supplementation. Reprod. Fertil. Dev. 2012, 24, 1040. [CrossRef]

22. Thompson, A.; Bairstow, C.; Ferguson, M.; Kearney, G.; Macleay, C.; Thompson, H.; Paganoni, B. Growth pattern to the end of the mating period influences the reproductive performance of merino ewe lambs mated at 7 to 8 months of age. Small Rumin. Res. 2019, 179, 1-6. [CrossRef]

23. Paganoni, B.; Ferguson, M.B.; Greeff, J.C.; Kearney, G.; Thompson, A.N. Liveweight and condition score at mating are both good predictors of reproductive rate for young Merino and Border Leicester Merino ewes across different Information Nucleus sites in Australia. Anim. Prod. Sci. 2014, 54, 727-735. [CrossRef]

24. Bunter, K.L.; Brown, D.J. Yearling and adult expressions of reproduction in maternal sheep breeds are genetically different traits. Proc. Assoc. Adv. Anim. Breed. Genet. 2013, 20, 82-85.

25. Hatcher, S.; Atkins, K.D.; Safari, E. Lamb survival in Australian Merino Sheep: A genetic analysis. J. Anim. Sci. 2010, 88, 3198-3205. [CrossRef] [PubMed]

26. Everett-Hincks, J.M.; Mathias-Davis, H.C.; Greer, G.J.; Auvray, B.A.; Dodds, K.G. Genetic parameters for lamb birth weight, survival and death risk traits1. J. Anim. Sci. 2014, 92, 2885-2895. [CrossRef]

27. Brien, F.D.; Cloete, S.W.P.; Fogarty, N.M.; Greeff, J.C.; Hebart, M.L.; Hiendleder, S.; Edwards, J.E.H.; Kelly, J.M.; Kind, K.L.; Kleemann, D.O.; et al. A review of the genetic and epigenetic factors affecting lamb survival. Anim. Prod. Sci. 2014, 54, 667-693. [CrossRef]

28. Young, J.M.; Behrendt, R.; Curnow, M.; Oldham, C.M.; Thompson, A.N. Economic value of pregnancy scanning and optimum nutritional management of dry, single- and twin-bearing Merino ewes. Anim. Prod. Sci. 2016, 56, 669-678. [CrossRef]

29. Griffiths, K.J.; Ridler, A.L.; Heuer, C.; Corner-Thomas, R.A.; Kenyon, P.R. The effect of liveweight and body condition score on the ability of ewe lambs to successfully rear their offspring. Small Rumin. Res. 2016, 145, 130-135. [CrossRef]

30. Horton, B.J.; Corkrey, R.; Hinch, G.N. Estimation of risk factors associated with difficult birth in ewes. Anim. Prod. Sci. 2018, 58, 1125-1132. [CrossRef]

31. Hinch, G.N.; Brien, F. Lamb survival in Australian flocks: A review. Anim. Prod. Sci. 2014, 54, 656-666. [CrossRef]

32. Jacobson, C.; Bruce, M.; Kenyon, P.R.; Lockwood, A.; Miller, D.; Refshauge, G.; Masters, D.G. A review of dystocia in sheep. Small Rumin. Res. 2020, 192, 106209. [CrossRef]

33. Refshauge, G.; Brien, F.D.; Hinch, G.N.; van de Ven, R. Neonatal lamb mortality: Factors associated with the death of Australian lambs. Anim. Prod. Sci. 2016, 56, 726-735. [CrossRef]

34. Clune, T.; Beetson, S.; Besier, S.; Knowles, G.; Paskin, R.; Rawlin, G.; Suter, R.; Jacobson, C. Ovine abortion and stillbirth investigations in Australia. Aust. Vet. J. 2021, 99, 72-78. [CrossRef] [PubMed]

35. Clune, T.; Besier, S.; Hair, S.; Hancock, S.; Lockwood, A.; Thompson, A.; Jelocnik, M.; Jacobson, C. Chlamydia pecorum detection in aborted and stillborn lambs from Western Australia. Vet. Res. 2021, 52, 84. [CrossRef]

36. Westermann, T.; Jenkins, C.; Onizawa, E.; Gestier, S.; McNally, J.; Kirkland, P.; Zhang, J.; Bogema, D.; Manning, L.K.; Walker, K.; et al. Chlamydia pecorum associated sporadic ovine abortion. Vet. Pathol. 2021, 58, 114-122. [CrossRef] [PubMed]

37. Clune, T.; Lockwood, A.; Hancock, S.; Bruce, M.; Thompson, A.N.; Beetson, S.; Campbell, A.J.; Glanville, E.; Brookes, D.; Trengove, C.; et al. Neospora caninum is not an important contributor to poor reproductive performance of primiparous ewes from southern Australia: Evidence from a cross-sectional study. Parasitol. Res. 2021, 120, 3875-3882. [CrossRef]

38. Clune, T.; Lockwood, A.; Hancock, S.; Thompson, A.N.; Beetson, S.; Bruce, M.; Campbell, A.J.; Glanville, E.; Brookes, D.; Trengove, C.; et al. Coxiella burnetii seroprevalence in primiparous and multiparous ewes from southern Australia: A cross-sectional study. Comp. Immunol. Microbiol. Infect. Dis. 2022, 80, 101727. [CrossRef]

39. Clune, T.; Lockwood, A.; Hancock, S.; Thompson, A.N.; Beetson, S.; Bruce, M.; Campbell, A.J.; Glanville, E.; Brookes, D.; Trengove, C.; et al. Toxoplasma gondii is not an important contributor to poor reproductive performance of primiparous ewes from southern Australia: A prospective cohort study. BMC Vet. Res. 2021. pre-print online. [CrossRef]

40. Buxton, D. Ovine toxoplasmosis: A review. J. R. Soc. Med. 1990, 83, 509. [CrossRef] 
41. Katzer, F.; Brülisauer, F.; Collantes-Fernández, E.; Bartley, P.M.; Burrells, A.; Gunn, G.; Maley, S.W.; Cousens, C.; Innes, E.A. Increased Toxoplasma gondii positivity relative to age in 125 Scottish sheep flocks; evidence of frequent acquired infection. Vet. Res. 2011, 42, 121. [CrossRef] [PubMed]

42. Jensen, R.; Miller, V.A.; Hammarlund, M.A.; Graham, W.R. Vibrionic abortion in sheep. I. Transmission and immunity. Am. J. Vet. Res. 1957, 18, 326-329.

43. Berri, M.; Souriau, A.; Crosby, M.; Crochet, D.; Lechopier, P.; Rodolakis, A. Relationships between the shedding of Coxiella burnetii, clinical signs and serological responses of 34 sheep. Vet. Rec. 2001, 148, 502-505. [CrossRef]

44. van Burgel, A.J.; Oldham, C.M.; Behrendt, R.; Curnow, M.; Gordon, D.J.; Thompson, A.N. The merit of condition score and fat score as alternatives to liveweight for managing the nutrition of ewes. Anim. Prod. Sci. 2011, 51, 834-841. [CrossRef] 